\title{
…....
}

\author{
「メモリーヘのレーザー応用小特集号」の発行にあたって \\ 江川 孝志 \\ 名古屋工業大学・極微構造デバイス研究センター（テ 466 愛知県名古屋市昭和区御器所町）
}

\section{Topical Papers on Applications of Lasers to Memory}

\author{
Takashi EGAWA \\ Research Center for Micro-Structure Devices, Nagoya Institute of Technology, Gokiso, Showa-ku, Nagoya Aichi 466
}

(Received June 6, 1997)

記録デバイスの大容量化, 高速化が重要な役割を担い, 近 年の電子産業の発展を支えてきた。マルチメディア時代 を切り開いてゆくためにも,光メモリーなどを用いた大容 量化, 高速化が必要であることは周知のとおりである。磁 気記録技術を用いたハードディスクやテープメディアは， これまでに大容量化を達成してきた。光ディスクメモ リーの高密度化をはじめとする半導体レーザー応用の拡 大という観点から, コンパクトなコヒーレント光源に対す る関心が高まっている。このような状沉を受けて, 本誌第 25 巻8号において,「メモリーへのレーザー応用」と題する小 特集号が組まれた。

現用コンパクトディスク $(\mathrm{CD})$ は, ピックアップ光源に波 長780nm帯のAlGaAs系半導体レーザーが使用されてい る.マルチメディアの世界では記録容量が数十GByteから 1TByteもの大容量メモリが必要であると予想される。現 在の光メモリ容量は光テープでは1TByte, 5.25インチ光磁 気(MO)デイスクでは約5GByte/diskである。読み出し専用 (ROM)ディスクのDVD (Digital Versatile Disc)は直径 120mm片面2層で9GByte, 両面4層のディスクで約18GByte となろう.マルチメディア時代の高密度記録を達成する ためには, なお一層の高密度化が必要である。 それには, キーコンポーネントである半導体レーザーの技術開発及 び新しい光メモリーシステムを開発することが必要不可 欠である。

光ディスクの記録密度の向上には, 集光スポットサイズ が波長に比例するという原理から, 光源の短波長化は本質
的要請であり,コンパクトな短波長光源の開発が注目され ている.とりわけ,ハイビジョンの記録再生を可能にする 青色光源に対する期待は大きく, $\mathrm{ZnSe}$ 系, $\mathrm{GaN}$ 系材料を用 いた半導体レーザー, 導波路型及びバルク型の第二高調波 発生 $(\mathrm{SGH})$ レーザーの試作など青緑色領域の光源の研究 が大きな進展をみせており,その実用化も近いと期待され る. 仮に, 波長 $400 \mathrm{~nm}$ の光源が使用できれば, 記録密度は現 状の約2倍になる.

$\mathrm{ZnSe}$ 系及びGaN系半導体レーザーでは, 室温連続発振動 作が達成され, 画期的なインパクトを与えた。現在, 実用 に耐えうるレーザーの信頼性, 寿命の改善という目標に向 けての競争が全世界的に繰り広げられていく。このよう な課題は, 結晶成長技術及びプロセス技術の発展により解 決され，実用化が達成されるものと期待される。

これらの背景をふまえ本小特集号では, メモリーへの レーザー応用に関する技術を取り上げ, メモリーへのレー ザー応用, 650nm帯半導体レーザー, メモリー用短波長半導 体レーザー, DVD-RAM記録媒体及びDVD-RAM用高出 力・高信頼半導体レーザーについて述べる.レーザー学 会編集委員からの小特集号企画のお誘いを,小野公三先生 (住友電気工業株式会社)とともにお引き受けさせていただ いた次第である。半導体レーザーを用いた光メモリー技 術がマルチメディア時代を支え, 我々に大いなる夢を与え てくれることを期待している．最後に, 投稿していただい た方々ならびに関係各位に深く感謝申し上げる. 